\title{
CONSTRUCTING THE ANTICHRIST AS SUPERSTAR: MARILYN MANSON AND THE MECHANICS OF ESCHATOLOGICAL NARRATIVE
}

\author{
PATRICK OSBORNE
}

\section{ABSTRACT}

This article examines the moral crusade against Marilyn Manson's Antichrist Superstar, the various sign-vehicles that contributed to his persona, and the social construction of a folk devil. By fashioning his persona using previous claims concerning Satan's influence in society-primarily, those employed during the 1980s Satanism scare-Manson ensured that Antichrist Superstar would incite panic as moral crusaders interpreted his pseudo-ostensive actions using collective memories and explanatory millenarianism. He achieved this aim by attacking middle-class Christian ideologies and connecting his persona to previous social problems and cultural scripts to delineate his deviant character. The pseudoostensive characteristics of Manson's stage performances and blasphemous lyrics grant creditability to traditional folk beliefs concerning Satan's influence in rock music therefore allowing conservative groups to interpret his persona using preexisting rumours and narratives. By presenting himself as the Antichrist, Manson became a social problem for fundamentalist Christianity: a reiterated moral panic greatly blown out of proportion, and produced using traditional exaggerations and deviant stereotypes in a collective attempt to construct a folk devil. Because Manson's image and lyrics are meticulously fashioned from various cultural symbols concerning evil and the Antichrist, he encourages his own demonization by enticing his audience to employ explanatory millenarianism and the knowledge of previous cultural scripts to interpret the traditional representations of evil he dangles before them.

\section{KEY WORDS}

Marilyn Manson, Persona, Moral panic, Eschatology, Satanism, Social Constructionism

Throughout the late-nineties, the self-proclaimed Antichrist Superstar, Marilyn Manson, spread a contagion of anxiety across America by exploiting Christianity's fear of Satan's presence in society. The band's grotesque image, anti-Christian ideology, and offensive lyrics addressing American taboos, such as sodomy, sadomasochism, fascism, and the destruction of God compelled many conservatives to deem Manson the "sickest group ever promoted by a mainstream record company" (Manson 1998, p. 262). By rejecting Christian hegemony, Manson incited cultural conflict: his tours prompted protest across the nation, his lyrics directed the Senate Subcommittee on Oversight of Government Management and Reconstructing to consider the effects of violent music on adolescents, and the Antichrist Superstar album became an 
exemplar of moral decay in American society. For a band claiming to be Dead to the World, an irony was apparent: Manson, styling himself as an ominous new voice for the Antichrist, was very much alive in 1997. Christianity thus found itself at war, and as Florence Hensell appropriately stated: Christian America was "fighting for God against Satan" (Manson 1998, p. 262). Threatened by the deterioration of traditional Christian values Manson represented, the American Family Association (AFA) protested the band and, to gain support for rallies against the Dead to the World tour, spread fictitious and defamatory affidavits advocating the satanic dangers Manson posed to America's youth.i Ironically, it was the AFA's moral crusade that made Manson a household name, gave credibility to his persona as the Antichrist Superstar, and illuminated the mechanics and rhetoric of eschatological narrative.

The purpose of the following essay is to examine both the antecedents and rhetoric surrounding the war against Antichrist Superstar, the various sign-vehicles that contributed to Manson's persona, and the social construction of a folk devil. While Manson has relatively remained out of public controversy since his connection to the Columbine Massacre in 1999, a semi-historical analysis of his persona provides insight into America's culture of fear and the diffusion of 'fake news' in what many deem a post-truth era. Glassner (2009) argues that feardriven legislation and media permit those in power to control moral principles and, in turn, enable criticism of undesirable groups and institutions to maintain hegemony (p. xxxi-xxxiv). In regards to a post-truth era, Frank (2015) identifies striking similarities between fake news reports and folklore and highlights the difficulties that arise from consumers' inability to distinguish fact from rumour. He suggests, "fake news bespeak our sophistication as news consumers. Our susceptibility to news hoaxes, on the other hand, reminds us of just how authoritative that news 'voice' continues to be, even amid an unceasing stream of complaints about inaccuracy, sensationalism, conflicts of interest, and bias" (p. 317). When coupled together, the dissemination of rumour and the rhetoric of fear incite a volatile catalyst for the construction and transmission of social problems that will be explored in relation to the moral panic surrounding Manson's Antichrist Superstar. Manson serves as a reminder concerning the power that fear maintains in America and contemporary society's vulnerability to false claims.

Best (1999) argues that "declaring war is simply one instance of a broader tendency to use militarized language to describe social problems" using a clearly understood metaphor that encourages open conflict with a unanimously chosen enemy (p. 144-145). As a product of a delineative process, social problems typically develop under three conditions: first, an individual or group must declare something or someone as a potential threat to normalcy. Subsequently, the perceived problem must stimulate a general cause for concern among a large population of people, and, finally, those individuals acknowledging the social problem must labour to eliminate the irritant through a collective moral crusade. In this sense, "social problems do not exist 'objectively' in the same sense that a rock, a frog, or a tree exists; instead, they are constructed by the human mind, called into being or constituted by the definitional process" (Best 1994, p. 151, italics in original). Eschatology provides a straightforward way for Christians to interpret various social problems, as Satan essentially causes the decline of Christian morals and the afflictions of Earth. The purpose of apocalyptic myth, Lamy (1996) argues, is "to make sense of the senseless, as a meaningful metaphor for those alienated or confused by society or their position in it, and [therefore serves] as a rallying point for social change or even revolution" (p. 38).

The perceived danger of listening to Manson's music and the inherent evils that have become seemingly synonymous with rock music can be viewed as an excellent case of the construction of a social problem, as Satan's influence on society cannot be objectively measured. Instead, the evidence for Satan's presence must be defined through an analysis of the moral 
deterioration of society; i.e. an individual's interpretation of the 'signs of the times.' Claims concerning Satanism therefore rely on the symbolism of a larger apocalyptic metanarrative, and ultimately stem from the reiteration of cultural patterns involving the diffusion of religious myths as a means of blaming scapegoats for social problems (Victor 1993, p. 75).

The witch-hunt that followed Manson throughout 1997-like many witch-hunts that preceded it-was the reiteration of various apocalyptic panics that have occurred throughout human history. From the vilification of the Jews in the middle ages, to the Salem witch trials, and just prior to Manson's arrival, the satanic panic of the 1980's, the Christian populace has instigated hysteria by utilizing cultural scripts composed of well-known legends and myths to demonize the enemies of Christ. Victor (1990) argues that "there are a number of genuine social evils in American society today, especially threats to the safety and well-being of children, which resemble the symbols of the legend[s]" concerning Satan's power in contemporary culture (p. 78). These symbols grant credibility to Satan's presence in society, and allow individuals to interpret enigmatic individuals and situations using traditional understandings of evil.

It was such apocalyptic and satanic symbols that made Manson and his Antichrist Superstar a phenomenal success as he effectively infused them in his persona. Marshall and Barbour (2015) argue, "persona helps us understand the construction, constitution, and production of the self through identity play and performance by the individual in social settings" (p. 2-3). Manson constructs his persona via numerous sign-vehicles derivative of the apocalyptic tradition that ultimately forced his Christian adversaries to interpret his enigmatic character using explanatory millenarianism. Manson in his autobiography, The Long Hard Road Out of Hell, delineates his understanding of the Antichrist tradition:

I've thought about being the Antichrist ever since the word was first taught to me at Christian school. In the Bible, the word antichrist is only used as a description of people who don't believe in the teaching of Jesus of Nazareth. He is not described as one satanic entity-as the beast of Revelation which many people believe-but as a person, any person, who deviates from Christian orthodoxy. But through years of myth-making and fear-sowing, Christianity metamorphosed antichrists into a single Antichrist, an apocalyptic villain and Christian bogeyman used to scare people much as Santa Claus is used to regulate children's behavior. (1998, p. 213, italics in original)

By viewing the Antichrist as the satanic figure needed to mirror Christ and create a threatening opponent to Christianity, Manson recognized the beast of Revelation as a metaphor constructed from both fear and resistance against the moral ambiguities of society.

This reinterpretation of the Antichrist serves two primary functions within Christian ideology: first, the unequivocal definition of the antichrist delineated by the author of 1 John provides an avenue for explicating the confusing and mythical elements of Revelation. Analyzing Revelation's symbolism in terms of a foreboding totalitarian world leader allows the mysterious beasts of the Bible to be re-arranged within Christian thought, for better understanding, using a clearly defined eschatological narrative. As Frykholm (2004) notes, "readers admit that Revelation is a struggle for them in their Bible reading because it is full of strange visions and bizarre images. They cannot read it literally," however by reinterpreting mythic creatures, such as a giant locust as a helicopter, the reader can "use the image of the locusts to offer a broader interpretation of contemporary life" (p. 120, 118). Because Christians cannot foresee an actual beast rising from the sea, the fantastic imagery of Revelation generates a sense of cognitive dissonance within believers. Fuller (1995) argues 
this dissonance could be reduced by interpreting world events against the background of apocalyptic myth. That is, the cryptic and evasive symbols associated with apocalyptic belief made it possible to see the 'signs of the times' being fulfilled and therefore gave reassurance that the divine timetable ... was nonetheless right on schedule. (p. 19)

Secondly, Because of Christianity's interpretation of "'signs of the times'" and the construction of the Antichrist into a single satanic being sent to destroy the modern world, the eschatological narrative subsequently shifts the threat of evil from the past and present to the imminent future. Hughes (2005) argues that "it is the sense of dreaded anticipation, even in the absence of a literal or predictive imminence, that fires desire to 'keep awake.' It is this 'sense of an ending,' the 'awareness that time is growing short' that gave early-medieval apocalyptic symbols their persuasive power" (p. 9). By granting the mythological beast of Revelation a face and sinister purpose, the eschatological narrative instills an anxious anticipation within the lukewarm Christian because the Antichrist could come at any moment. Furthermore, as Fuller (1995) argues, "belief in the Antichrist invokes a mythic framework for interpreting the cognitive dissonance and vacillating intellectual that believers, particularly the young, often find themselves struggling against... [as] unacceptable doubts are explained away as the tactics of a treacherous enemy" (p. 170).

The eschatological narrative therefore allows the believer to perceive all forms of social malaise as the work of Satan and a sign that the foreboding Antichrist is present on Earth. For this reason, the believer develops a compelling desire to interpret the 'signs' to alleviate both the neophobia and anxiety of influence generated by the Antichrist's perceived presence in society (Parker 2007, p. 10). Frykholm (2004) notes that "the narrative lays out a formulaic series of events and characters. Believers do the work of filling in the blanks in order to understand and give shape to the world they live in" (p. 120) and goes on to argue that "Evangelicals seek to 'read' the contemporary world through this mythological structure, variously interpreting the scene at different historical moments" (p. 120). Such explanatory millenarianism appraises the current problem using eschatological narrative, and allows Christians "to analyze current affairs in terms of sacred prophecy. [For example,] a recent earthquake, a terrorist bomb, the spread of homosexuality, or even an international trade agreement shows that the End is not far off" (Thompson 2005, p. 27). This Christian methodology for explicating the present using the terminology of a larger apocalyptic metanarrative is vital for understanding the many appearances of the Antichrist that have occurred throughout human history. As Fuller (1995) argues, "over the last two hundred years, the Antichrist has been repeatedly identified within such 'threats' as modernism, Roman Catholicism, Jews, socialism, and the Soviet Union. Today, fundamentalist Christian writers see the Antichrist in such enemies as the Muslim world, feminism, rock music, and secular humanism" (p. 5).

Understanding the explanatory and combative desires underlying eschatological narrative, Manson marketed Antichrist Superstar to challenge and trouble fundamentalist Christianity. Hjelm's (2014) use of the term "secondary symbolism" provides insight into Manson's marketing strategies. Employing a labeling theory approach, Hjelm argues controversies surrounding metal music are often a product of "secondary deviation" in which "a person or group internalizes the controversial label given to them from the outside and starts to act according to role expectations" (p. 164). Hjelm claims, "symbols, paraphernalia, t-shirts and so on which are considered 'satanic' are displayed because it is part of identifying with the genre, not because of a personal commitment to a particular worldview" (p. 170-171). Manson, in accordance with secondary deviation, thus becomes "a symptom of something much more 
pervasive, a much deeper social memory, and there is a massive groping toward some cultural trough abounding in signs of social decay" (Gunn 1999, p. 421).

Manson employs sign-vehicles derivative of the apocalyptic tradition "to be the loudest, most persistent alarm clock [he] could be, because there didn't seem to be any other way to snap society out of its Christianity-and media-induced coma" (Manson 1998, p. 80). He achieves this aim by attacking middle-class Christian ideologies and connecting his persona to previous social problems and cultural scripts to delineate his deviant character. For this reason, Wright (2000) argues that Manson clearly surpassed his "heavy metal forebears by painstakingly deconstructing contemporary North American culture and 'mutating' (his word) into a prophetic persona whose essence is to be reviled, condemned and ultimately sacrificed by that culture" (p. 377, italics in original). Such deconstruction deliberately leaves Manson's incomprehensible actions open to interpretation, and, because his image and lyrics are meticulously fashioned from various cultural symbols concerning evil and the Antichrist, Manson encourages his own demonization by enticing his audience to utilize explanatory millenarianism to readily define the traditional representations of evil he dangles before them.

Manson ensures his demonization through the employment of both religious and folk symbols. Marilyn Manson-as the name itself evinces-is a carefully constructed amalgam of cultural icons and motifs that, while being attractive to rebellious youth, can be easily understood as overtly satanic iconoclasm by conservative parents of a past generation. As Wright (2000) notes, Manson's

pseudonym plays on 1960s-era pop cultural iconography, while Antichrist Superstar spoofs Jesus Christ Superstar, the 1970 'rock opera'... His make-up is borrowed from rather obvious 1970s-era sources, including Alice Cooper and slasher movies. . . [and] he made his first splash on MTV with a 'demonic' cover of Eurythmics' adult contemporary radio staple, 'Sweet Dreams (Are Made of This)' - a strategy he likened to 'a piece of cheese in a trap.' (p. 379)

Direct linkages between Manson and social problems of the past allow parents to assign him an identity by interpreting the band's overtly satanic symbolism. Cohen (1972) suggests, for the construction of a folk devil, "imagery is an integral part in the identification process: the labels are not invented after the deviation. [Rather,] the labelers ... have a ready-made stock of images to draw upon. Once the initial identification has taken place, the labels are further elaborated" (p. 74). Manson's Antichrist Superstar and demonic façade provided his audience with the necessary images to initiate this labeling process. He embodies the claimsmaker's understandings of evil and through his secondary symbolism incorporates the deviant label into his persona to appeal to the cognizance of previous cultural scripts concerning Satan's influence in rock music.

Best (2001) argues that, "social problems do not develop in a vacuum. Claims about one social problem often influence those about another: claimsmakers borrow rhetoric and tactics from one another; in some cases, experienced claimsmakers join efforts to call attention to other social problems" (p. 2). Manson has indubitably studied the traditional folk beliefs concerning the Antichrist's influence in society, and has incorporated cultural scripts concerning Satanism into his persona to stir anxieties and reinforce previous claims by moral crusaders. For this reason, Manson's persona and stage performances are rich in what folklorists define as pseudoostension, or the deliberate reenactment of well-known folk narratives to deceive and/or frighten. For example, individuals that masquerade as Satanists or even fabricate evidence of ritual abuse to frighten their communities are performing pseudo-ostensive behaviours. Heavy 
metal musicians that employ backward masking, pentagrams or other satanic symbols in their artistry act from similar impulses (Ellis 1989, p. 209).

Manson's performances are vivid displays of pseudo-ostension that validate claims concerning Satanism and are rich with what Bettez Halnon (2006) describes as the carnivalgrotesque:

In heavy metal carnival, the grotesque body is dramatized by a communal flow of human excretions ... For example, in a parodic inversion of good and evil, sacred and profane, this-worldly and other worldly, and life and death, 'Reverend' Marilyn Manson (of LeVay's Church of Satan) engages in baptismal (life-giving, purifying, renewing) spitting at the audience from a profanely branded water bottle. (p. 37)

Manson's stage performances reinterpret Christian iconography and, like most folk beliefs concerning satanic cult ceremonies, present the iconoclastic spectacle as a blasphemous reversal of traditional church services. This is important, as Ellis (2001) notes, because "to the extent that Satanism does exist in folklore, it exists as an 'antiworld,' a deliberate protest against institutionalized norms. This means that whatever structure exists in folk Satanism derives from institutional structures, which they adopt in mirror image" (p. 1). In his most controversial stage performance, Manson impersonates the Antichrist: a totalitarian dictator that artificially blows kisses to the audience while tearing-or, in some cases, burning-pages from the book of Mormon while convulsing inside an oversized pulpit. Manson, acting as a demonic preacher, demands his audience "Repent" ironically presenting the Christian church as a fascist regime and delineating an antiworld of satanic ritualism.

Manson's Antichrist Superstar presents a methodology for mutating into the allAmerican Antichrist using Christianity's eschatological narrative and the claims-making process. Manson presents his work as a prophetic text by employing several motifs prevalent in apocalyptic works: "common to apocalyptic writing is their tendency to be pseudonymous, to use mythic imagery, and build on a series of narrative 'cycles' that repeatedly describe and resolve the community's spiritual turmoil” (Fuller 1995, p. 21). Manson's Antichrist Superstar meticulously follows the apocalyptic tradition, as he breaks the album into three distinct cycles delineating his triumph over Christian oppression and the satanic rebirth he achieves through the self-discovery of the Nietzschean 'higher man'. Throughout the three cycles, Manson chronologically presents his metamorphoses from an insignificant wormboy into a threatening rock star, and concludes the album with his ascension to the position of the Antichrist Superstar advocated by fundamentalist Christianity and the eschatological myth.

The first cycle of Antichrist Superstar, "Hierophant," illuminates the oppressive Christianity that enslaves the wormboy and ultimately encourages Manson's rebellion and selfvilification. The album opens with "Irresponsible Hate Anthem," a song that serves as a negative toast advertising the horrible qualities of Manson and greatly contributes to his deviant persona. In the opening lines of "Irresponsible Hate Anthem" Manson (1996) declares, "I am so all-American, I'd sell you suicide / I am totalitarian, I've got abortions in my eyes." Within the first two lines of the album, Manson openly challenges the values of Christian America, discloses himself as an enemy of established religion, i.e. a totalitarian Antichrist, and rhetorically appeals to the individual most likely to interpret and combat a perceived threat to spirituality using eschatology: the blue-collar Christian that uncritically holds traditional family values as the measure of stability in a given society and perceives patriotism as a significant cultural value (Victor 1993, p. 55). By mocking America and promoting suicide, totalitarianism, and abortion, Manson becomes evil in the eyes of Christianity "because [believers] tend to view their nation as 
uniquely blessed by God"; those that threaten the American way are often labeled Antichrists and must be eradicated to maintain normalcy (Fuller 1995, p. 5). "Irresponsible Hate Anthem" therefore serves as the Antichrist Superstar's introduction to Christian society and acts as an attack on American culture and traditional family values. Manson iconoclastically likens "Irresponsible Hate Anthem" to the "Star Spangled Banner" in concert, and will often burn or use the American flag as toilet paper during performances of the song (Halnon 2005, p. 37). Accordingly, Manson opens the album by attacking Christian America to condone his own vilification and incite explanatory millenarianism for interpreting his demonic characterization. Manson desires to be viewed as the Antichrist and uses "Irresponsible Hate Anthem" as a method for providing his audience with the deviant labels in which to readily interpret his ambiguous persona.

Manson, however, longs to be hated not for the sole purpose of gaining notoriety but rather to demonstrate the Christian hypocrisy that causes many individuals to rebel from religion. Manson's opening track, while elucidating Manson's villainous actions, simultaneously suggests that Christian America is irresponsibly hating and constructing its own demise by "kill[ing] everyone" defined a villain and letting "god sort them out" (Manson 1996).

Accordingly, Manson "has appropriated moral panic throughout his career, and his purpose has been twofold: to reveal the hypocrisy and corruption of the so-called normal world, and to portray himself ... [as] someone who is constructed by a corrupt society" (Conaway 2010, p. 109).

Kinnaman and Lyons (2007) note that almost $80 \%$ of non-Christians and over half of Christians that attend church regularly perceive the church as being overtly judgmental (p. 185). The primary goal of Manson's Antichrist Superstar is to expose this judgmental behavior and present, as Manson (1998) writes, Christianity's "disgusting similarities to Nazi Germany" (p. 263). For this reason, Antichrist Superstar is rich with imagery pertinent to Hitler's Third Reich: the Antichrist Superstar album is represented by an insignia that bears a close resemblance to the sieg rune, and Manson's stage show often "resembles a fascist rally more than a rock concert" (Baddeley 2005, p. 123). Manson employs these images, of course, to invoke a direct connection with Hitler: a man that was given the moniker of the Antichrist throughout WWII. Furthermore, totalitarianism is a major theme of Christianity's eschatological narrative, as Revelation foretells that Christians will be forced to bare the mark of the New World Order or be put to death. For this reason, Manson desires to be linked to totalitarianism (as "Irresponsible Hate Anthem" brazenly suggests) because it provides his Christian audience with the necessary symbols to interpret his persona as the Antichrist. In addition, Manson's utilization of fascist imagery provides the album with its ironic allegorical message: Antichrist Superstar presents Christianity as a fascist regimen that rejects all notions of tolerance and strives to eradicate anyone that deviates from religious values.

Manson's beliefs concerning Christianity and his illustrations of religious oppression closely follow the philosophy outlined in Nietzsche's The Antichrist. In promotional interviews for Antichrist Superstar, Manson suggests the album is "like the superman theory that Nietzsche had, I think every man and woman is a star ... If you want to have people tell you how to see [the world], then you can. But if you want to look at it, then it's limitless what you can do" (qtd. in Baddeley 2005, p. 131). Nietzsche suggests in The Antichrist that Christianity "has waged a war to the death against this higher type of man, it has banned all the basic instincts of this type, it has distilled 'evil' and the 'Evil One' himself, out of these instincts" (2005, p. 5, italics in original). To win the war against the "higher man," Nietzsche suggests anyone that attempts to gain knowledge or physical happiness is labeled by Christianity as a deviant that must be snuffed out. The primary goal of Antichrist Superstar is to illustrate this holy war as a fascist 
genocide that destroys anyone deemed evil and, in turn, present a methodology for overcoming such oppression by embracing a deviant nature.

Antichrist Superstar's second track, "The Beautiful People," continues implementing Manson's themes of Christian totalitarianism and constructs auditory images of an army preparing for war using distinctive militaristic drumbeats. Ellis (2008) notes that "The Beautiful People' featured the zombie groove, possessed vocal hiss, and sinister intent that came to characterize [Manson's] general oeuvre, while the song's lyrics portrayed a ragged class of mindless and threatening subhumans, by-products of warped Darwinism on the verge of an impending cutthroat fascism" (p. 264). The beautiful people to which Manson alludes in the songs title are fundamentalist Christians that deem everything that deviates from religious values as ugliness: they are the Christians delineated in Nietzsche's The Antichrist, that "want to rule over beasts of prey; its method is to make them sick-weakening is the Christian recipe for domestication, for 'civilization'” (2005, p. 19, italics in original). Reiterating the philosophy outlined in Nietzsche's The Antichrist, Manson (1996) states to the wormboy that "it's not your fault that you're always wrong / the weak ones are there to justify the strong." Throughout the song, the wormboy has been made feeble-held down by his Christian oppressors-and can only survive his intolerable situation by reversing the master/slave dialectic and becoming "the animal that will not be himself" (Manson 1996).

The final song of the first cycle, "Tourniquet," shares similar motifs with Antichrist Superstar's opening tracks by demanding Christianity "take your hatred out on me." Manson desires to become the scapegoat, or tourniquet, that can stop the bleeding and aid Christianity in its attempt to regain hegemony. Manson argues in "Tourniquet" that he will achieve this aim using Antichrist Superstar to become a "prosthetic synthesis with butterfly /sealed up with virgin stitch." Albeit a cryptic image, Manson's illustration depicts the transfiguration of the wormboy into a threatening higher man. The image depicts two fake bodies, Manson and the Church, being conjoined by an exigency concerning the spiritual welfare of virginal children. Manson, playing the role of the Antichrist, strives to tempt America's children from Jesus therefore leaving the Church the obligation to fight for their salvation. The two entities become inexorably linked as they rely on each other for a sense of purpose due to a desire to eradicate its counterpart. Because of this Christian interest, the wormboy gains power and perpetuates his satanic rebirth. The second cycle, "The Inauguration of the Worm," thus begins with "Little Horn": a song that provides the album's first direct connection with the biblical Antichrist. Daniel writes that he had a dream about four terrible beasts, one of which had a little horn that "was making war against the saints" (Dan. 7:21). This fourth beast with the "little horn" is often linked to the Antichrist of Revelation by theologians. By identifying himself as Little Horn, Manson continues his self-vilification as an antichrist and, for this reason, transfigures into a threating rock star via his secondary deviation.

The seventh track of Antichrist Superstar, "Deformography," presents the album's overarching thesis. "Deformography," of course, acts as a pun on the word "demography": the social science of studying human populations. Demography is important to the rise of the Antichrist Superstar, as it is essentially the study of Christianity's attempts at self-preservation that grants the insignificant wormboy his power. "Deformography" offers Manson's most lucid blueprint for becoming the Antichrist in Christian America: Manson (1996) growls, "I will bury your God in my warm spit, / you'll be deformed in your porn." Manson suggests that his iconoclasm will incite Christians' defensive mentality, their employment of explanatory millenarianism to define a perceived threat, and the construction of a folk devil via the oftenpornographic folklore that accompanies spiritual warfare. The application of eschatology grants Manson power and identity, as he embraces everything Christianity labels him: for Manson 
(1998), to be the Antichrist an individual simply needs to be viewed as one. Manson writes in his autobiography that "by telling people he was a Satanist [Anton] LaVey became Satan in [the public's] eyes-which is not unlike my attitude toward becoming a rock star. 'One hates what one fears,' LaVey had written. 'I have acquired power without conscious effort, by simply being'” (p. 165).

Christian vilification aggrandizes Manson to the position of the Antichrist Superstar as the album reaches its title track and the first song of the third cycle. "Antichrist Superstar" offers a panoramic picture of Manson's rise to power: "You built me up with your wishing Hell / I didn't have to sell you" (Manson 1996). Eschatology encourages a self-fulfilling prophecy as Christianity labels anyone and everything that deviates from God as a "sign of the times," thus forcing every generation to believe that theirs will mark the return of Christ and the inevitable apocalypse. Manson suggests in "Antichrist Superstar" that the apocalyptic tradition and explanatory millenarianism has granted him the tools to gain infamy; rather than persuading his audience he simply looked the part. Prophetically addressing the libelous defamations of his character spread by various religious groups, Manson (1996) states: "I am the hydra / Now you'll see your star." Manson employs the allusion to the hydra perfectly, as it suggests Christian attacks will only strengthen his campaign against Christianity: it gives the Antichrist its power and ultimately proves the thesis of Antichrist Superstar.

The pseudo-ostensive characteristics of Manson's carnival-grotesque and blasphemous lyrics (albeit parodies), grant creditability to traditional folk beliefs concerning Satan's influence in rock music therefore allowing concerned parents to interpret his onstage antics using preexisting rumours and narratives. Feldman-Savelsberg, T. Ndonko and Yang (2005) argue that

collective memory is thus related to rumor in at least two ways. First, collective memories create fertile ground for the reception of rumor; within the structures of collective memory, certain truth claims 'make sense,' are linked to a set of beliefs and attitudes about the nature of the social order, and thus appear plausible to the audience of rumor ... Second, collective memories, including memories of past rumors, can actually contribute to the production of new rumors; speakers may draw upon or refer to the past events in their creation of new rumors. (p. 60)

Manson plays to collective memory in his pseudo-ostensive actions and directly connects himself to past social problems. The success of Manson's music and the blatantly iconoclastic spectacles of Manson's Dead to the World tour that ran from September 1996 to September 1997 piqued the interest and enmity of the AFA: an organization seeking to "restrain evil by exposing the works of darkness" ("Action Statement," AFA). After interpreting Manson's lyrics and performances as overtly satanic, the AFA launched a highly organized campaign to battle the perceived threat. The war against Manson resulted in a media driven mass-hysteria and incited a rumour-panic precipitated by the AFA's libelous affidavits propagated by previous cultural scripts.ii

Many of the claims produced during the war against Manson, reiterate warnings about Satanism that had developed in the previous decade:

During the 1980's, elements of apparently unrelated social movements converged in the cause of antisatanism. Each movement brought its own concepts and concerns. Five precursor movements-fundamentalist Christianity, the anticult movement, the developments of 'satanic churches,' the new wave of child saving, and the survivor/recovery movement-made 
particular important contributions to social construction of the satanist menace. (Richardson, Best and Bromely 1991, p. 5-6).

Manson ensures his music and image will incite moral panic by addressing the fears of the five precursor movements, a marketing strategy that allowed him to gain notoriety by rehashing claims of a past generation. Thus, rumour and contemporary legend elevated Manson to the status of the Antichrist Superstar by granting him a mythical folk identity and allowing him to become a cultural phenomenon.

The name Manson, for example, has a strong cultural resonance in American society. A vivid connection between Charles Manson and Marilyn Manson is inevitable and grants a previously unknown band the same status as an established cultural icon. Charles Manson, as Ellis (2001) illustrates, was "interpreted by the media as the leader of a satanic cult, and ... [h] is ability to hold [a] loose assemblage of dropouts together gained him a reputation for hypnotic powers, and stories soon circulated that while in prison he had learned how to implant 'subliminal motivations' into the minds of his fellow inmates" (p. 171). In fact, it was the publicity that surrounded Charles Manson's trial that first transformed the word "cult" into a potentially dangerous, satanic body that opposed traditional values in the eyes of many Americans (Victor 1993, p. 9). By including the name, "Manson," into his pseudonym, Marilyn Manson implies that his music can hypnotize and force his audience to do things against their will: a suggestion playing to previous warnings of the anticult movement, and a preconceived fear many have concerning rock music. Indubitably, Manson's design succeeded as rumours began circulating that, during the Dead to the World tour, Manson adopted runaways into his circle of friends, and that, invoking Charles Manson again, he called them his "Family" (Manson 1998, p. 245).

As mentioned, Manson argues in his autobiography that to become Satan in society's eyes an individual simply needs to look like a Satanist; for him, becoming a threatening rock star is no different (Manson 1998, p. 165). For decades,

heavy metal music and Satanism [have been] synonymous for many adults, particularly since some musicians have in fact been influenced by occult writers like Aleister Crowley and many others have incorporated satanic trappings into their music and stage acts ... Some critics have gone so far as to say that the songs are satanically inspired and, if played backward, reveal subliminal messages magically inducing the listener to commit suicide or worship Satan. (Ellis 1990, p. 44)

Understanding the stigma rock music holds, Manson plays to these parental fears by mimicking and adopting the traditional folk beliefs concerning Satan's power in rock music. In 1994, Manson befriended Anton LaVey, a man who gained notoriety in 1969 from the publication of the Satanic Bible, and was ordained a Reverend in LaVey's Church of Satan. Due to Manson's pseudo-ostensive actions, rumours began circulating that "Manson perform[s] a Satanic church service toward the end of the concert in which he preaches from the Satanic Bible, and ... gives and invitation to receive Satan into your life" (Manson 1998, p. 256). Manson claims in his autobiography (1998) that "the day I became a Satanist also happened to be the day the allied forces of Christianity and conservatism began mobilizing against me. Just after our meeting [with LaVey], I was told that the Delta Center, where we were to play in Salt Lake City, would not allow us on the bill" (171).

The AFA spread even more horrific rumours about Manson's pre-concert actions: 
Manson will come out on stage by himself dragging a big bag either just before the band starts playing or the band will start jamming and then stop abruptly as Manson comes out with the big bag. I have witnessed Manson pull out small chickens, several puppies and kittens out of the bag and throw them into the audience. These are live animals ... Manson will then tell the audience to make a sacrifice to the music and he will not start the show until all the animals are dead. (Manson 1998, p. 254)

Both rumours employ claims from the past and appropriate the cultural scripts from subversion and blood libel myths. Victor (1993) notes, "Satanic cult rumor stories derive from an ancient legend, usually referred to as the 'blood ritual myth.' It tells the story of children being kidnapped and murdered by a secret conspiracy of evil strangers" (p. 75). The blood ritual legend is often combined with the subversion myth, i.e. the continual spiritual battle between Christ and Satan, and strengthens the power of the claim by appealing to both secular and sacred symbols (Victor 1993, p. 77). Note that this story has Manson bringing out the bag of animals alone, for he, and no one else, serves as the scapegoat for all the satanic decadence in America. The bag consists of only infantile animals that serve as symbols for America's children that are likely to be ripped apart by the horrific message of Manson. Lastly, Manson is said to force an ultimatum on the impressionable youth by demanding that they sacrifice the animals or go without a show. This statement is of upmost importance as it suggests that the youth of America have a choice: they are not willing to sacrifice animals or themselves without the influence of a satanic being. Thus, the rumorus suggest that Manson, as a destructive satanic force, must be stopped while simultaneously implying that, by endorsing the AFA's moral crusade, Christianity can deter Manson's influence.

As Victor (1993) notes, satanic cult rumours gain power and credibility by appealing to both religious and secular symbols. Rumour suggests that Manson is not only a spiritual threat to impressionable children, but a physical threat as well. The industrial style of music that influenced Antichrist Superstar permitted the incorporation of masked messages that resemble the subliminal verses that compel the adolescent listener to commit suicide in traditional folk narratives. For example, Antichrist Superstar includes a hidden track in which Manson (1996) mumbles: "God will crawl at my feet" and "when you are suffering, know that I have betrayed you": an allusion to Aleister Crowley's The Book of the Law. Manson likewise incited controversy when he began marketing a T-shirt that read: "Warning: The music of Marilyn Manson may contain messages that will KILL GOD in your impressionable teenage minds. As a result, you could be convinced to KILL YOUR MOM \& DAD and eventually in a hopeless act of suicidal 'rock and roll' behavior you will KILL YOURSELF” (Manson 1998, p. 259; emphasis in original).iii Albeit satirical, the T-shirt and the masked messages contained in Antichrist Superstar grant credibility to folk beliefs concerning Satan's influence in rock music and reinforce claims surrounding a preconceived social problem affecting youth culture: a strategy often used in heavy metal music for shock value rather than a religious witness (Richardson 1991, p. 210). As Wright (2000) claims, "Marilyn Manson is a semiotic threat from deep within the dominant culture. He knows full well that he is playing, not only with inter-generational dynamite, but with the legacy of the PMRC, the neoconservative right, the censorship lobby, the hegemony of banal rock radio and, above all, the thoroughly fraudulent claim that rock music causes teen suicide. A tee-shirt for sale at his concerts summarises his agenda succinctly" (380).

During a period of high anxiety concerning the effects of media on America's youth, the Senate Subcommittee on Oversight of Government Management and Reconstructing met to discuss violence in music. Manson's Antichrist Superstar was one of the most cited albums throughout the discussions due to its extreme references to violence and suicide. On November 6th, 1997, Raymond Kuntz testified against Manson stating that, "his 15-year-old son killed 
himself last December after listening to songs about death and the Antichrist" (Stout 1997, p. 21). Manson's violent lyrics, hidden messages, and his own suggestions that his music could induce a listener's self-inflicted death, permit bereaved parents to claim a correlation between Manson's music and their children's suicides. Although most adolescent fans did not adopt the antisocial behaviors illustrated in albums such as Antichrist Superstar (Bostic, et. al 2002, p. 54), the folk narrative concerning the influential power of rock music allows parents to find closure and solace in the form of therapeutic magic: the rumour allows the distraught parent to interpret an ambiguous act of suicide in the terms of a clearly defined mythology, i.e. the devil made the child do it (Ellis 1990, p. 44). Concerning his son's suicide, Kuntz argued, "the music wasn't symptomatic of other problems. I would say the music caused him to kill himself" (Stout 1997, p. 21). By using Satan's influence as a coping mechanism, blame is projected onto the scapegoat and feelings of parental failure are avoided through the construction of a social problem. Furthermore, Kuntz's statements strengthen traditional folk beliefs, as he becomes a rumour carrier: 'Rumor 'carriers' do not create the satanic cult rumor stories. However, they make use of them to enhance their own ideology. They also lend credibility to the rumor stories, because of their positions of authority" (Victor 1990, p. 75). Through his pseudo-ostensive actions and self-effacing lyrics, Manson presents himself as a potential scapegoat for distraught parents and benefits from negative publicity when labeled as such. Conaway (2010) notes, "Manson does not call for the death of the art of scapegoating, but instead, appropriates scapegoating narratives, making himself a martyr ... in order to point out, in Shaw-like fashion, the unacceptability of the discourse of moral panic and its efforts to condemn the youth culture of his fans" (p. 105).

Manson's self-vilification and lyrics appeal to previous concerns of satanic conspiracies and present his message as a threat to a child's physical safety. By the late 90 s, the satanic ritual abuse narrative had been highly discredited. However, Manson weaves nuances of these tales into his image and rehashes the legends by donning the persona of The Child Catcher. Manson makes use of overtly satanic symbolism and addresses incendiary topics like child abuse in his second album, Smells Like Children (Baddeley 2005, p. 42). The album cover features a photo of Manson resembling the Child Catcher from the 1968 film, Chitty Chitty Bang Bang, and features "Kiddy Grinder": a song providing a direct warning to parents that all Manson (1994) wants "is just your children." By addressing child abuse in his presentation and music, Manson links himself to a past social problem; he becomes the satanic criminal threat that will not hesitate to physically harm your child as his "fists are lined with suckers" (Manson 1994). Manson's persona plays on the collective memories of the 1980s Satanism scare and reinforces previous claims of ritual abuse. For this reason, the AFA's narratives concerning Manson's Dead to the World tour adopt these previous understandings of Satanist recruitment strategies, and strive to demonstrate his criminal influence to appeal to a secular audience.

While Kuntz's suicide acted as an actual case concerning Satan's potential threat to adolescents, many rumours concerning satanic cults often employ the techniques of conspiracy theories and gain credibility through apocryphal stories about individuals that escaped the dangerous lifestyle. Champion-Vincent (2005) argues that individuals typically accept conspiracy stories that present the following cognitive attributes: First, an evil agent is named and given a specific evil purpose. The villain has the power to cause a massive disturbance to normalcy, and, finally, the individuals that accept the claims generally agree that the conspiracy has taken place before (p. 104-105). Conspiracy stories are crucial to the antisatanist's rhetoric in that it redefines a religious social problem in secular terms, thus making it applicable to nonChristians. These conspiracy narratives tend to present the Satanist as a criminal threat. The tales characterize the Satanist as a murderer, kidnapper, drug addict, or child molester: problems that even the most skeptical individual can view as a threat to children. Ottens and 
Myer (1998) provide a detailed discussion concerning the threat Satanism poses to adolescents and offer warning signs for concerned parents in their book, Coping with Satanism: Rumor, Reality, and Controversy. Taking a conspiracy approach, Ottens and Myer argue Satanists often lure children into their practices using similar methods of urban gangs. Satanists appeal to outcasts by involving them in parties and other social activities, and strive to get the child addicted to drugs. During drug-induced states, the Satanist will brainwash the child and use blackmail to keep the child from leaving the group (p. 77-88).

The AFA's affidavits suggest that $100 \%$ of the audience at a Manson concert are high on drugs and, consequently, children as young as nine years old are induced to have sex in the audience (Manson 1998, p. 256). In addition, Manson supposedly engaged in a game called "Blood Bath" in which a group of Manson's friends, the "Family," murdered a young girl in a sacrificial act of satanic vampirism (Manson 1998, p. 258). Albeit sensationalized, the AFA's libelous affidavits create ethos by employing the "occult survivor" story: a powerful technique used by moral crusaders during the 1980's Satanism scare that negated the lack of physical evidence for satanic crimes using testimonies and first-person accounts of individuals that witnessed the horrors of Satanism first hand (Best 1991, p. 99). The affidavits concerning Manson demand credibility from such first-person accounts: "I [name withheld] hereby swear, affirm, declare and affitt: 1 . I am a seventeen year old male and reside at [address withheld] Oklahoma City, Oklahoma [zip withheld]. 2. Three years ago I was a runaway fourteen years old when I first met Marilyn Manson (Brian Warner) and was accepted by him into his circle of friends or "family" (Manson 1998, p. 246). Such tales typically involve a recently "born-again" survivor that, after witnessing such horrors as satanic worship, blood drinking, and deviant sexual acts, flees from the cult group to safety (Jenkins and Maier-Katkin 1991, p. 127). Accordingly, the AFA's affidavits suggest the runaway began fearing for their own safety following the "Blood Bath" ritual and refused to return to Manson's circle after turning their life around and giving their "life to the Lord Jesus Christ" (Manson 1998, p. 258).

The rumours and libelous affidavits aimed at destroying Manson transformed him into an ominous juggernaut and ultimately made him a household name. Without the mass hysteria and rumour panic surrounding Manson and Antichrist Superstar, many Americans would, perhaps, not be aware of him today. Governor Keating-illustrating his understanding of Manson-argues that "from what [he had] learned of the content of their lyrics and message as well as their conduct on stage, [Marilyn Manson] are clearly bent on degrading women, religion and decency, while promoting Satanic worship, child abuse and drug use" (Manson 1998, p. 262). In regards to the infamous shirt sold at Manson's concerts, Senator Shugars stated "[he] was not even aware of a group called Marilyn Manson until ... [he heard] their message is kill God, kill your parents and then commit suicide" (Manson 1998, p. 262). In both cases, the state leaders were not aware of Manson until they heard about his pseudo-ostensive actions and the apocryphal stories constructed by the AFA. Manson is a cultural phenomenon dependent on Christian interpretation and his persona is ultimately a representation of evil in popular music that gains infamy by being defined as such. As Manson (1998) suggests, "everything and everyone that tried to beat the album down had only made it stronger, more powerful and more effective" (p. 244). Antichrist Superstar therefore serves as a warning concerning the power fear maintains in contemporary society and how the distribution of 'fake news' can create chaos. Employing a wonderfully appropriate image of his persona's development via eschatological narrative, Manson (1994) appropriately warns Christian America in "Rock n' Roll Nigger": "I am the all-American Antichrist / I was made in America, /And America hates me for what I am / I am your shit. /You should be ashamed of what you have eaten." 
By constructing his image using claims concerning Satan-primarily, those employed during the 1980s Satanism scare-Manson ensured that his music would incite panic as moral crusaders interpreted his pseudo-ostensive actions and deviant persona using previous collective memories and explanatory millenarianism. As Baddeley (2005) notes, the music is "seldom the most interesting part of the Marilyn Manson package," for "Marilyn Manson is a monster stitched together from the pieces of a thousand other creatures" (p. 12). Manson, as a persona, is more reliant on presentation and shock value derivative of cultural scripts than lyrical content. Consequently, Manson is an entity that exists almost entirely in the folk-realm as rumour and contemporary legend constructed his identity and took his band mainstream. By presenting himself as the Antichrist, Manson became a social problem for fundamentalist Christianity: a reiterated moral panic greatly blown out of proportion, and produced using traditional exaggerations and deviant stereotypes in a collective attempt to construct a folk devil. Manson provoked his audience using pseudo-ostensive displays of Satanism and forced many individuals to interpret his nefarious façade using the knowledge of past social problems. Thus, Manson gains power via social constructionism: he becomes the devil worshiper, the Antichrist, an ominous "sign" that the world is coming to an end.

\section{END NOTES}

i Mirapaul (1997) of the New York Times writes, "a better place to find depraved entertainment could well be on the Internet, where descriptions of Manson's concerts are given by some of his detractors. In anonymous affidavits bearing January dates, two Oklahoma City youths stat [e] that Manson and his ensemble perform Satanic rites onstage and engage in sex acts with animals and each other... Until two weeks ago, the debauchery-drenched text of the affidavits could be found right where you'd expect it to be: on the Web site of the Gulf Coast American Family Association, an affiliate of Rev. Donald Wildmon's national Christian organization." Covering the mass-hysteria that surrounded Manson's tour, Boehlert (1997) states "moralists have been protesting the antics of Marilyn Manson -- whose outlandishly savvy, button-pushing frontman is a self-professed minister of the Church of Satan -- since the late-1996 release of their latest album, Antichrist Superstar. Communities including Richmond, Va., Columbia, S.C., and Rutherford, N.J., have tried, with varying degrees of success, to sidetrack the band's shows. But in recent weeks, it has become clear that the religion-fueled outbursts are not just impulsive expressions of local concern -- they're an odd mixture of old-time tent revivals and high-tech information campaigns spread via the Internet. 'People were clearly sent, faxed or e-mailed information here,' says Will Berkheiser, general manager at the Utica Memorial Auditorium, in Utica, N.Y. The hysteria surrounding Manson's shows began to take on strikingly similar patterns, often with the same public (and false) accusations made against the band. Berkheiser received only a handful of complaints following the announcement of Manson's Utica show and then, weeks later, was suddenly inundated with calls of protest. 'It's almost like something was planned,' he says" (p. 27). The affidavits were removed from the web in 1997 following Manson's threats to sue for libel, however were reprinted in Manson's autobiography: The Long Hard Road Out of Hell. Therefore, all references to the affidavits in this essay derive from Manson's text.

ii Strauss (1997) notes in Rolling Stone that "ever since Marilyn Manson formed, in 1990, rumors have stuck to the band's frontman like the eyeliner that he wears onstage. Even selfprofessed fans have speculated on the Internet that Manson planned to kill himself during a show last Halloween, that he removed a rib so he could perform fellatio on himself and that he cut off his testicles. Manson has done little to rectify these obvious lies. 'I never dispel rumors, because people can believe what they want,' he explained last year. Now that the rumors are 
coming from his enemies instead of from his fans, Manson has been doing a lot of dispelling -- to police officers, legislators, concert officials and parents" (p. 18).

iii Manson's controversial T-shirts were also connected to several legal battles. John Schroeder was arrested on obscenity charges for wearing Manson's T-shirt with the slogan "I am the God of Fuck" in a grocery store (Bendersky 1998), and, in 2001, "the U.S. Supreme Court declined to hear the appeal of a high school student who was barred from wearing Marilyn Manson T-shirts to school. The justices declined without comment to hear the appeal of Nicolas J. Boroff, who was a 17-year-old senior at Van Wert High School in Ohio in 1997 when he got into trouble for wearing T-shirts of the Gothic rock group, whose lead singer also performs under the name Marilyn Manson ... A panel of the appellate court ruled 2-1 last year that the school had the authority to prohibit T-shirts that 'contain symbols and words that promote values that are so patently contrary to the school's educational mission'”' (Walsh 2001, p. 29).

\section{WORKS CITED}

American Family Association, "Our mission," retrieved 10 May 2017, <http://afa.net>.

Baddeley, G 2005, Dissecting Marilyn Manson, Plexus Publishing, London.

Bendersky, A 1998, 'Marilyn Manson t-shirt sparks controversy,' Rolling Stone, retrieved 10 May 2017, < http://www.rollingstone.com/music/news/marilyn-manson-t-shirtsparkscontroversy-19980130>.

Best, J 1991, 'Endangered children and antisatanist rhetoric,' in J T. Richardson, J Best, \& D Bromley, (eds), The satanism scare, pp. 95-106. Aldine De Gruyter, New York.

Best, J 2001, How claims spread: cross-national diffusion of social problems, Aldine de Gruyter, New York.

Best J 1999, Random violence: how we talk about new crimes and new victims, University of California Press, Berkeley.

Boehlert, E 1997, 'Manson Mania,' Rolling Stone vol. 762, no. 2, pp. 27-28, retrieved 10 May 2017, Academic Search Complete.

Bostic, JQ., Schlozman S, Pataki C, Ristuccia C, Beresin E \& Martin A 2003, 'From Alice Cooper to Marilyn Manson: the significance of adolescent antiheroes,' AcademicPsychiatry vol. 27, no. 1, pp. 54-62, retrieved 10 May 2017, Springer Link.

Champion-V 2005, 'From evil others to evil elites: A dominant pattern in conspiracy theories today,' in GA Fine, VC Vincent \& C Heath, (eds), Rumor mills: The social impact of rumor and legend, pp. 103-122. Aldine Transaction, New Brunswick.

Cohen, S 1972, Folk devils and moral panics: the creation of mods and rockers, MacGibbon \& Kee, London.

Conaway, C 2010, 'Manson's R+J: Shakespeare, Marilyn Manson and the fine art of scapegoating,' in EB Christian, (ed), Rock brands: selling sound in a saturated media culture, Lexington Books, Blue Ridge Summit.

Ellis, B 1989, 'Death by folklore: ostension, contemporary legend, and murder,' Western Folklore, vol. 48, no. 3, pp. 201-220, retrieved 10 May 2017, JSTOR.

Ellis, B 1990, 'The devil-worshipers at the prom: rumor-panic as therapeutic magic,' Western Folklore, vol. 49, no. 1, pp. 27-49, retrieved 10 May 2017, JSTOR.

Ellis, B 2000, Raising the devil: Satanism, new religions, and the media, University Press of Kentucky, Lexington.

Ellis, I 2008, Rebels with attitude: subversive rock humorists, Soft Skull Press, Washington.

Feldman-S, Pamela, Ndonko F \& Yang S 2005, 'How rumor begets rumor: collective memory, ethnic conflict, and reproductive rumors in Cameroon' in GA Fine, VC Vincent \& C Heath, 
(eds), Rumor mills: the social impact of rumor and legend, pp. 103-122. Aldine Transaction, New Brunswick.

Frykholm, AJ. 2004, Rapture culture: left behind in evangelical America, Oxford University Press, Oxford.

Fuller, RC 1995, Naming the Antichrist: the history of an American obsession, Oxford University Press, New York.

Glassner, B 1999, The culture of fear: why Americans are afraid of the wrong things, Basic Books, New York.

Goode, E \& Ben-Yehuda N 1994, 'Moral panics: culture, politics, and social construction,' Annual Review of Sociology, vol. 20, pp. 149-171, retrieved 10 May 2017, JSTOR.

Goode, E \& Ben-Yehuda N 1994, Moral panics: the social construction of deviance, Blackwell, Oxford.

Gunn, J 1999, 'Marilyn Manson is not goth: memorial struggle and the rhetoric of subcultural identity,' Journal of Communication Inquiry, vol. 23, no. 4, pp. 408-431, retrieved 10 May 2017, Sage Journals.

Halnon, KB 2006, 'Heavy metal carnival and dis-alienation: the politics of grotesque Realism,' Symbolic Interaction, vol. 29, no. 1, pp. 33-48, retrieved 10 May 2017, JSTOR.

Hjelm, T 2015, 'Controversial popular culture and controversial religion: theorising the connections,' in K Granholm, M Moberg \& S Sjö, (eds), Religion, media and social change, pp. 162-174. Routledge, New York.

Hughes, KL 2005, Constructing Antichrist: Paul, biblical commentary, and the development of doctrine in the early middle ages, Catholic University of American Press, Washington D.C.

Jenkins, P \& Maier-Katkin D 1991, 'Occult survivors: the making of a myth,' in J T. Richardson, J Best, \& D Bromley, (eds), The satanism scare, pp. 127-144. Aldine De Gruyter, New York.

Kinnaman, D \& Lyons G 1996, Unchristian: what a new generation thinks about Christianity... and why it matters, Baker Books, Grand Rapids.

Lamy, P 1996, Millennium rage: survivalists, white supremacists, and the doomsday prophecy, Plenum Press, New York.

Manson, M 1996, Antichrist Superstar, [CD] Nothing/Interscope.

Manson, M 1998, The long hard road out of Hell, Regan Books, New York.

Manson, M 1995, Smells Like Children, [CD] Nothing/Interscope.

Marshall, D \& Barbour K 2015, 'Making intellectual room for persona studies: a new consciousness and a shifted perspective,' Persona Studies, vol. 1, no. 1, pp. 1-12, retrieved 10 May 2017, $<$ https://ojs.deakin.edu.au/index.php/ps/article/view/464/489>.

Mirapaul, M 1997, 'The traveling controversy that is Marilyn Manson,' The New York Times on the Web, The New York Times Company, retrieved 12 May 2017, $<$ https://partners.nytimes.com/library/cyber/mirapaul/042497mirapaul.html>.

Nietzsche, F 2005, The anti-Christ, ecco homo, twilight of the idols: and other writings, trans A Ridley and J Norman. Cambridge University Press, Cambridge.

Ottens, A \& Myer R 1998, Coping with Satanism: rumor, reality, and controversy, Rosen Publishing Group, New York.

Parker, J 2007, The aesthetics of antichrist: From Christian drama to Christopher Marlowe, Cornell University Press, Ithaca.

Richardson, JT, Best J \& and Bromley D 1991, 'Satanism as a social problem,' in J T. Richardson, J Best, \& D Bromley, (eds), The satanism scare, pp. 3-20. Aldine De Gruyter, New York.

Richardson, JT 1991, 'Satanism in the courts: from murder to heavy metal,' in J T. Richardson, J Best, \& D Bromley, (eds), The satanism scare, pp. 205-220. Aldine De Gruyter, New York.

Russel, F 2015 'Caveat lector: fake news as folklore," Journal of American Folklore, vol. 128, no. 509, pp. 315-332, retrieved 10 May 2017, ProQuest.

Stout, D 1997 'A hearing focuses on lyrics laced with violence and death,' New York Times, retrieved 10 May 2017, ProQuest.

Strauss, N 1997, 'Stage fright,' Rolling Stone, vol. 763, pp. 18-19, retrieved 10 May 2017, Academic Search Complete. 
Persona Studies 2017, vol. 3, no. 1

Thompson, D 2005, Waiting for antichrist: charisma and apocalypse in a Pentecostal church, Oxford University Press, Oxford.

Victor, J 1990, 'Satanic cult rumors as contemporary legend," Western Folklore, vol. 49, no. 1, pp. 51-81, retrieved 10 May 2017, JSTOR.

Victor, J 1993, Satanic panic: the creation of a contemporary legend, Open Court Publishing , Chicago.

Walsh, M 2001, 'Supreme court lets stand ruling that gives schools right to restrict t-shirts,' Education Week, vol. 20, no. 28, pp. 29, retrieved 10 May 2017, Academic Search Complete.

Wright, R 2000, 'I'd sell You Suicide": pop music and moral panic in the age of Marilyn Manson,' Popular Music, vol. 19, no. 3, pp. 365-385, retrieved 10 May 2017, JSTOR. 